\title{
HORIZONTAL DRILLING: \\ REGULATORY AND CONTRACTUAL IMPLICATIONS
}

\author{
R.E. PELZER and R.A. LEHODEY*
}

Recent technological developments have allowed the petroleum and natural gas industry to drill horizontal wells on a cost-effective hasis. Although the tec/mology is still relatively new in Canada, it has potentially significam benefits to the industry. including greater flow rates per well and greater ultimate recovery of petroleum substances. It has been estimated that by 1995 there may be as many as 450 horizontal wells drilled in Alherta per year. The implications of horizontal drilling are that the current regulatory schemes and certain of the common agreements utilized in the industry do not readily accommodate it. The authors discuss some of the legal implications raised by the new technology and examine problems with the current regulatory schemes and certain industry agrecments.

\section{TABLE OF CONTENTS}

I. INTRODUCTION ...................... 273

II. EXPLANATION OF HORIZONTAL DRILLING $\ldots \ldots \ldots \ldots 273$

A. WHAT IS HORIZONTAL DRILLING ........... 273

B. ADVANTAGES AND DISADVANTAGES

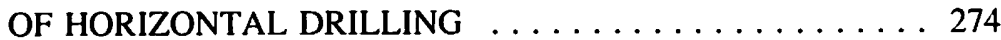

C. NUMBER OF HORIZONTAL WELLS

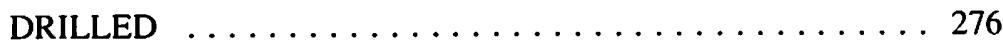

III. REGULATORY APPROACHES $\ldots \ldots \ldots \ldots \ldots \ldots \ldots \ldots 276$

IV. CORRELATIVE RIGHTS $\ldots \ldots \ldots \ldots \ldots \ldots \ldots \ldots \ldots \ldots \ldots \ldots$

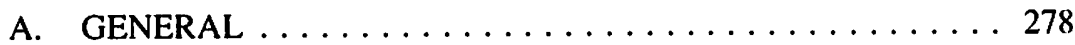

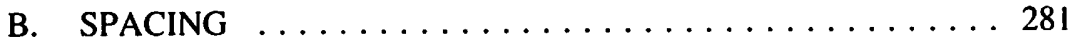

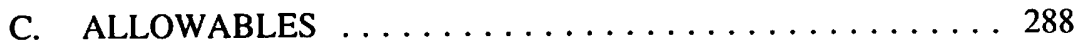

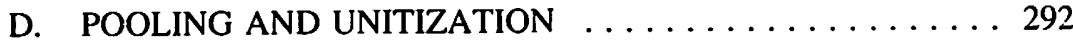

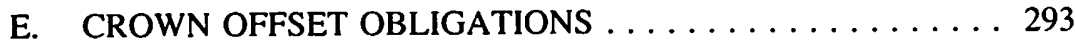

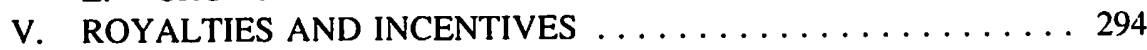

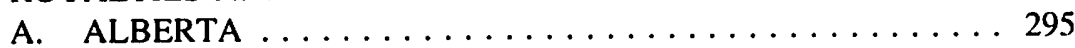

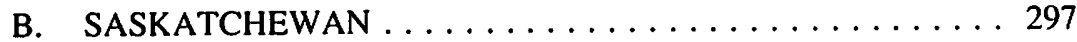

VI. INDUSTRY AGREEMENTS . . . . . . . . . . . . . . . . 297

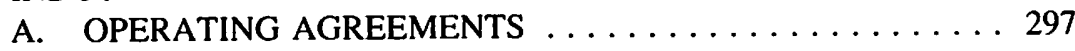

B. FREEHOLD LEASES . . . . . . . . . . . . . . . . . 299

C. ROYALTY CONSIDERATIONS $\ldots \ldots \ldots \ldots \ldots \ldots \ldots 304$

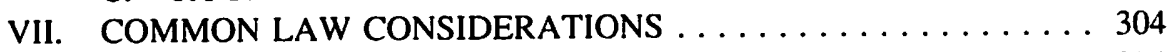

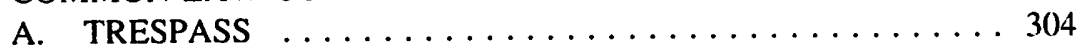

B. IMPLIED COVENANTS $\ldots \ldots \ldots \ldots \ldots \ldots \ldots \ldots \ldots \ldots \ldots \ldots$

VIII. CONCLUSION ....................... 307

Robert A. Lehodey is a partner with the law firm of MacKimmie Matthews. At the time of writing this article Robert E. Pelzer was the Vice-President and General Counsel of Conoco Canada Limited. He is now a Senior Legal Advisor with Conoco (U.K.) Limited in London. England. 


\section{INTRODUCTION}

Recent technological developments have allowed the petroleum and natural gas industry to drill wells horizontally for significant distances on a cost effective basis. The existing regulatory system and industry agreements evolved without contemplation of this new technology. As a result a number of legal issues have been raised respecting these regulatory schemes and agreements.

This paper provides, by way of introduction, a brief explanation of horizontal drilling and explains why it is expected that the number of horizontal wells drilled in Western Canada will expand significantly over the next few years. The writers then address some of the regulatory and contractual issues raised by this new technology with focus on Alberta and Saskatchewan, the two jurisdictions in Canada in which most horizontal drilling has occurred.'

The purpose of the paper is to make the reader aware of some of the issues that will be raised as this technology is used more extensively throughout the industry. The only prediction we can make with certainty is that we will not have predicted all of the legal issues that will be raised by the new technology over the next few years.

\section{EXPLANATION OF HORIZONTAL DRILLING}

\section{A. WHAT IS HORIZONTAL DRILLING?}

Horizontal drilling is the term used in industry to describe the technique of drilling a vertical hole, and gradually changing the direction of the drilling bit as the hole reaches the target zone or contract depth until the hole approaches the horizontal. The objective is to have the horizontal portion of the hole in the target formation. This has the effect of exposing more of the producing formation to the well bore. If, for example, a formation is five metres thick, a vertical well through the formation will be in contact with the formation for five metres. A horizontal well bore on the other hand can, depending on the circumstances, be in contact with the producing formation for well over 1,000 metres.

The Industry - Saskatchewan Energy and Mines Task Force Report on Regulatory Framework for Horizontal Wells released in final form on 11 March 1991 (the

\footnotetext{
Al the time of submission of this paper to The Canadian Petroleum Law Foundation for the 30th Annual Research Seminar in Oil and Gas Law, the Saskatchewan legislature had recently (1 May 1991) completed the first reading of Bill No. 73 of 1990-91. An Act to amend The Oil and Gas Conservation Act ("Bill 73"). Since Bill 73 is not yet law, and as it was only received by the writers on May 10, 1991 from the Saskatchewan Department of Justice. Civil Law Division, we have attempted to highlight the implications of the proposed amendments to the existing Saskatchewan legislation by way of footnotes throughout this paper. Those footnotes remain in this published version and the reader is advised that the amendments in Bill 73 have now been passed into law. Consequently reference should be made to the final amended version of The Oil \& Gas Conservation Act for the Province of Saskatchewan.
} 
Saskatchewan Task Force Report) suggests that for the purposes of amending the Saskatchewan legislation, a horizontal well be defined as follows:

... a well drilled at an angle of at least 80 degrees to the vertical and with a minimum horizontal projection of 100 metres measured from the initial point of penetration into the productive formation through the terminus of the lateral in the common source of hydrocarbon...2

\section{B. ADVANTAGES AND DISADVANTAGES OF HORIZONTAL DRILLING}

Since the use of this technology is relatively recent, there is considerable disagreement as to the ultimate value of horizontal drilling. Proponents argue that horizontal drilling will revolutionize the industry, vastly increasing production and reserves of oil and gas, and resulting in the majority of wells being drilled horizontally within a few years. Detractors argue that horizontal drilling is just a passing fad which is of only limited value in a limited number of reservoirs. As usual, the truth probably lies somewhere in the middle. At the very least it appears we will see a significant number of horizontal wells drilled in Canada over the next few years in an attempt to ascertain if the technology can deliver on its promised benefits.

Proponents argue that horizontal drilling has the following advantages:

Greater flow rates per well - A horizontal well can generally produce at significantly greater flow rates than a vertical well in the same formation. The greater the flow rate the greater the cash flow and the sooner the investment is paid out. According to the Alberta Department of Energy, experience in Alberta to date has shown productivity for horizontal wells up to five times greater than the average productivity for vertical wells in the same pool. ${ }^{3}$

Greater ultimate recovery - The total amount of oil or gas ultimately recovered from a reservoir can be significantly increased by horizontal drilling. It has been estimated that "up to 35 billion barrels of additional oil equivalent could be recovered with horizontal technology in the United States over a 20 year period." ${ }^{14}$ Oilweek Magazine has estimated that horizontal well drilling could increase Canada's recoverable oil reserves by $50 \% .^{5}$ The Alberta Department of Energy has estimated that horizontal drilling has the potential to increase Alberta's crude oil reserves by up to $30 \%{ }^{6}$

2. Saskatchewan, Energy and Mines Task Force Report on Regulatory Framework for Horizontal Wells, II March 1991 at 2.

3. Alberta Department of Energy, Horizontal Well Royaly Regime Backgrounder, 2 April 1991.

4. P.C. Crouse, "A Review of the Reservoir Considerations for Horizontal Wells in the Bakken Formation," presented at the 1990 Calgary Horizontal Drilling Conference, August 1990.

s. C. Donville, "Making Hole Sideways Gives Oil Patch New Lease," The Globe and Mail Report on Business, 29 March 1991.

6. Supra, note 3 . 
Greater drainage area per well - The fact that each horizontal well can drain a greater area than a vertical well means that fewer wells are required to develop a field. Thus horizontal drilling presents a number of advantages while also reducing:

(a) the cost of production and gathering facilities as fewer wells need to be connected to the system,

(b) the costs of permitting, site preparation and restoration as fewer wellsites are required, and

(c) the environmental impact of field development as less surface area is utilized. The environmental advantages of horizontal drilling may become more significant as environmental restrictions become more stringent. It may be particularly important in developed areas where the impact of drilling can be drastically reduced by the use of horizontal drilling. In fact the Alberta Energy Resources Conservation Board (ECRB) has indicated that it may require the use of horizontal drilling in certain environmentally sensitive areas. ${ }^{7}$

Economic development from reservoirs not suitable or not economic for development by conventional vertical wells - Even the detractors, who doubt the value of horizontal drilling in formations that can be economically produced by vertical wells, acknowledge that horizontal drilling shows great promise in the following types of reservoirs:

(a) thin, large area pay zones,

(b) low permeability pay zones,

(c) pay zones damaged by high flow rates (e.g. coning), and

(d) pay zones characterized by vertical fractures.

Detractors argue that horizontal drilling has the following disadvantages:

Cost - It costs more to drill a horizontal well than a vertical well. As with most developing technologies however, the cost of horizontal drilling has decreased. For example, the cost of horizontal wells drilled by Oryx Energy Company in the Austin Chalk formation in Texas has been reduced from between $\$ 600$ and $\$ 1200$ per lateral foot in the first wells drilled to $\$ 300$ per lateral foot. ${ }^{8}$ The current rule of thumb seems to be that a horizontal well drilled and completed to the same depth as a vertical well will cost twice what the vertical well will cost. Engineers familiar with the technology seem confident that this differential can still be significantly reduced as experience levels rise and the technology is further developed.

Completion, stimulation and workover technology is lagging - The ability to drill horizontal wells has improved rapidly, but the technology to complete these wells for production, the ability to stimulate them by fracing or otherwise and the ability to

7. D. Lehmann et al, "A Regulatory Perspective on Horizontal Wells in Canada," presented at 1990 Calgary Horizontal Drilling Conference, August, 1990 at 12.

x. J. Burtner, "Horizontal Well Completion Technology," presented at the 1990 Calgary Horizontal Drilling Conference. August 1990. 
rework them after they have been producing for some time has not developed as rapidly and there is still considerable room for improvement.

Unproven reserve increases - It may be too early in the life of the technology to determine if it really results in a greater ultimate recovery than vertical drilling rather than just increased production rates. Although valid theoretical arguments can be made that horizontal drilling will result in greater ultimate recovery, this has yet to be proven conclusively in practice.

\section{NUMBER OF HORIZONTAL WELLS DRILLED}

The following table shows the number of horizontal wells drilled in Alberta and Saskatchewan in recent years:

\begin{tabular}{||c|c|c||}
\hline & Saskatchewan & Alberta \\
\hline Before 1987 & None & 5 \\
\hline 1987 & 1 & 12 \\
\hline 1988 & 3 & 13 \\
\hline 1989 & 13 & 27 \\
\hline 1990 & 77 & 29 \\
\hline
\end{tabular}

In Texas there were 127 horizontal wells drilled in 1990 and it is estimated there will be over 1,000 drilled in 1991. The fact that Saskatchewan has overtaken Alberta significantly in the number of horizontal wells drilled appears to be largely due to the more favourable royalty regime in Saskatchewan as discussed below. It has been estimated there will be 450 horizontal wells per year being drilled in Canada by $1995 .{ }^{\prime}$ We suggest this optimistic projection will be met only if many of the regulatory issues discussed in this paper can be resolved.

\section{REGULATORY APPROACHES}

In regulatory jurisdictions in the United States there have been two approaches taken to horizontal drilling. The first approach has been to adopt specific rules and regulations to deal with horizontal drilling. The second approach has been to stretch existing regulations developed for vertical wells to cover horizontal wells. In summary: 
Wyoming, Oklahoma and Texas have recently adopted specific horizontal well rules and regulations while Montana, North Dakota, Nebraska. Colorado, New Mexico, Utah and Califomia review and permit both verticals and horizontals under long standing regulations."'

Saskatchewan has recently adopted the first approach by proposing specific legislation and regulations to deal with horizontal wells. In fact on 1 May 1991 the Saskatchewan legislature completed the first reading of Bill 73 of 1990-91, An Act to Amend the Oil and Gas Conservation Act (Bill 73)" which is intended, among other things, to address the increasing use of horizontal drilling. Alberta continues to use the second approach, by employing the existing regulations.

The approach taken by the regulatory agencies in each particular case seems to be largely a function of how optimistic they are about the future of horizontal drilling. The more optimistic they are, the more willing they appear to make the effort to formulate specific rules and regulations. In Alberta the ERCB is of the view that:

In the matter of, energy conservation, the ERCB is optimistic about the potential of increased ultimate recoveries resulting from the appropriate application of horizontal well technology. However, thus far. there is insufficient information to quantify the magnitude of that potential.'2

In Saskatchewan the view is summarized as follows:

Horizontal drilling is recognized as one of the most significant technological advancements in the petroleum industry in recent years. It holds considerable promise for the industry and the province. ${ }^{13}$

Clearly the Saskatchewan regulatory authorities are more convinced of a bright future for horizontal drilling than are the Alberta regulatory authorities.

Utilizing the discretionary powers in existing regulations to permit horizontal wells has the advantage of flexibility for an emerging technology. On the other hand the need for the regulatory agency to make a discretionary decision in each case can be both a time consuming process for the applicant and the regulatory agency and could lead to subjective and inconsistent results. The existence of specific rules and regulations for horizontal wells as proposed in Saskatchewan expedites the approval process for wells complying with the rules and provides objective and ascertainable criteria which allow the proponent of a horizontal well to plan with more certainty.

10. C.H. Farmer, "Regulatory Issues of Horizontal Wells," Wyoming Oil and Gas Conservation Commission, presented at 1990 Calgary Horizontal Drilling Conference, August, 1990.

11. Supra, note I.

12. Energy Resources Conservation Board Draft \#5 of Information Lelter 90- regarding Horizontal Wells at 1 .

13. Supra, note 2 at 1. 


\section{CORRELATIVE RIGHTS}

\section{A. GENERAL}

Increased production rates attributed to horizontal wells have sparked some controversy as to the equitable entitlement to petroleum and natural gas between competing working interest owners. "Correlative Rights" is a term used to describe certain rights and duties arising between parties holding interests in petroleum and natural gas substances contained in the same reservoir. Those rights and corresponding duties have evolved both under common law and by legislation. Under common law a party holding an interest in petroleum and natural gas substances is entitled to a fair and equitable share of production. Through conservation legislation limits have been placed on production from reservoirs to prevent physical and economic waste.

The migratory nature of oil and gas gave rise to the development in the common law of the rule of capture, a "legal rule for non-liability for (1) causing oil or gas to migrate across property lines and (2) producing oil or gas that was originally in place under the land of another, so long as the producing well does not trespass." ${ }^{14}$ This rule has been stated as follows:

The owner of a tract of land acquires title to the oil and gas which he produces from wells thereon, though it may be proved that part of such oil and gas migrated from adjoining lands. ${ }^{15}$

The rule of capture was originally formulated in early judicial decisions in the United States which recognized an unrestrained right of capture, permitting an operator of an oil or gas well to produce it, even wastefully, without regard to the prejudicial effect of production upon reservoir conditions, notwithstanding that other persons owned oil and gas interests in lands overlying the same reservoir. ${ }^{16}$

The common law evolved in the United States in such a fashion that the rule of capture has been modified to a certain extent by the "fair share or ownership in place rule." The rule entitles each owner of an interest in petroleum substances to acquire its equitable share of the petroleum substances in a common reservoir in the proportion to which the recoverable reserves attributable to its interests bears to the recoverable reserves in the reservoir. ${ }^{17}$ The evolution of such rights and the legislative concern for the committing of waste has led to a recognition in the United States "that there are some correlative rights and duties of persons holding interests in oil and gas in a common reservoir existent under common law and that reasonable additional ones can validly be imposed by legislation." 18

1.8. Williams \& Meyers, Mamual of Oil and Gas Terms, 7th ed. (1987) at 869.

15. Hardwick, "The Rule of Capture and its Implications as Applied to Oil and Gas" (1935) 13 Texas L. Rev. 391 at 393.

16. Lewis \& Thompson, Canadian Oil and Gas, vol. I (Toronto: Butterworths, 1954), sec. 44.

17. Supra, note 14 at 340.

ix. Supra, note 16, s. 45. 
A definition of the term correlative rights is cited by Williams \& Meyers as follows:

[T]he opportunity afforded, so far as it is practical to do so, to the owner of each property in a pool to produce without waste his just and equitable share of the oil or gas, or both, in the pool; being an amount, so far as can be practically determined, and so far as can be practically obtained without waste, substantially in the proportion that the quantity of recoverable oil or gas, or both, under such property bears to the total recoverable oil or gas, or both, in the pool, and for such purposes uses a just and equitable share of the reservoir energy..$^{19}$

Canadian legislatures, with the benefit of exposure to the development of United States oil and gas law, have established conservation legislation with stated objectives consistent with the development of the common law and emergence of conservation legislation in that country. The Oil and Gas Conservation Act (Alberta) (the Alberta Act) provides, in section 4, that:

The purposes of this Act are:

(a) to effect the conservation of, and to prevent the waste of, the oil and gas resources of Alberta;

(b) to secure the observance of safe and efficient practices in the locating, spacing, drilling, equipping, completing, reworking, testing, operating and abandonment of wells and in operations for the production of oil and gas;

(c) to provide for the economic, orderly and efficient development in the public interest of the oil and gas resources of Alberta:

(d) to afford each owner the opportunity of obtaining his share of the production of oil or gas from any pool;

(e) to provide for the recording and the timely and useful dissemination of information regarding the oil and gas resources of Alberta;

(f) to control pollution above, at or below the surface in the drilling of wells and in operations for the production of oil and gas and in other operations over which the [ERCB] has jurisdiction."

Similarly, The Oil and Gas Conservation Act (Saskatchewan) (the Saskatchewan Act) provides, in section 3 , that:

The purposes of this Act are:

(a) to prevent waste;

(b) to regulate all operations for the production of oil and gas in such manner that the greatest possible ultimate recovery thereof by prudent and proper operations and practices may be realized:

(c)

to protect the correlative rights of each owner; 
(d) to enable each owner to obtain his just and equitable share of the allowable production of any pool;

(e) to develop, process, utilize, protect and conserve the oil and gas resources of Saskatchewan for use in the province by the people of Saskatchewan; and to protect the environment with respect to operations of the oil and gas industry. ${ }^{21}$

The Saskatchewan Act addresses the protection of the correlative rights of each owner as a stated purpose although that term is not defined anywhere in the legislation. ${ }^{22}$ Although the Alberta Act does not specify as a purpose the protection of correlative rights, the regulations to the Alberta $\mathrm{Act}^{23}$ (the Alberta Regulations) do provide for the making of rules respecting rates of production "in the interests of conservation or the protection of correlative rights." ${ }^{24}$ Again that term is not defined.

The leading Canadian case Borys v. Canadian Pacific Railway and Imperial Oil Limited indicates that the rule of capture is entrenched in the Canadian common law. ${ }^{25}$ However, in that case the court pointed out that exercise of the rule was to be subject to applicable legislation. Canadian case law has not, as a result of the introduction of conservation legislation in the 1930 's,${ }^{26}$ developed significantly with respect to correlative rights and in fact there is no definition of that term in the Canadian common law.

Hence, although correlative rights are not formally recognized in the Canadian common law, the provinces through legislation such as the Alberta Act and the Saskatchewan Act achieve the objectives stated therein. ${ }^{27}$ This is accomplished by establishing rules and regulations relating to spacing units for drilling and production, allowable rates of

21. R.S.S. 1978, c. O-2.

22. Bill 73 proposes to amend section 3 of the Saskatchewan Act by repealing paragraphs 3(c) and 3(d) and replacing them with the following:

to allow each owner the opportunity of obtaining that owner's share of the oil or gas from a pool;

Additionally, the words "for use in the province by the people of Saskatchewan" are to be deleted from paragraph 3(e). Finally, the following subsections are added:

Nothing in subsection (1) requires the minister to ensure that each owner receives the owner's precise share of the oil or gas from any pool.

The minister may determine when the public interest requires that one purpose set out in subsection (1) be given priority over another.

The proposed paragraph 3(1)(c) appears to be patterned significantly after paragraph 4(d) of the Alberta Act and the additional subsections $3(2)$ and $3(3)$ clearly provide the Minister with the discretion, without the obligation. to protect the correlative rights of working interest owners.

Oil and Gas Regulations, Alta. Reg. 151/71.

Ibid. s. 10.120.

[1953] 2 D.L.R. 65.

The Oil and Gas Resources Conservation Act. 1938, S.A. 1938, c.15.

Supra, notes 20 and 21. 
production, and pooling and unitization regimes all with a view to preventing physical and economic waste of petroleum substances and permitting equitable sharing of production by the owners of such petroleum substances in a particular reservoir.

The problem, arising as a result of the development of the technology which enables economic drilling of horizontal wells, is that the current legislation and associated regulations do not readily accommodate the unique attributes of horizontal wells which have an impact upon both conservation practices and correlative rights. Conservation practices and the rights of working interest owners with respect to the production of oil and gas are governed under such legislation predominately by the rules and regulations relating to spacing units, ${ }^{28}$ allowable production rates ${ }^{29}$ and pooling and unitization. ${ }^{310}$

\section{B. SPACING}

In Alberta and Saskatchewan, the traditional or normal spacing has been 160 acres for an oil well ${ }^{31}$ and 640 acres for a gas well. ${ }^{32}$ Both regulatory regimes provide for discretion in alteration of spacing unit size upon application. In the case of heavy oil, where horizontal drilling has attracted great interest, spacing units of considerably less than 160 acres per well are usually permitted.

Horizontal wells have been drilled in the North Sea with horizontal displacements exceeding 5,000 feet. Clearly horizontal well technology has the capacity to cross existing spacing unit boundaries. In many cases it has been, and will continue to be, geologically advisable to do so and, in the case of some of the smaller spacing units, impossible not to do so. The regulatory authorities in Alberta and Saskatchewan have recognized that the full potential of horizontal drilling cannot be tested or realized if there is strict adherence to the traditional spacing rules. As noted above, the authorities of these two provinces have taken different approaches to addressing the issue of spacing for horizontal wells. $I(g . I)$ and $I(r)$ respectively by reference to the regulations. The Saskatchewan Act defines the term "drainage unit" in clause 2(d).

In the Alberta Act the term "allowable" is defined in clause I(1)(a) and in the Saskatchewan Act the terms "allocated production," "allowable production" and "allowable" are defined in clause 2(1)(a). Bill 73 would amend the Saskatchewan Act by repealing clause 2(1)(a). There is no replacement definition in Bill 73 however presumably one will be included in amendments to the regulations to the Saskatchewan Act.

30. In the Alberta Act, Part 12 deals with pooling and unitization and in the Saskatchewan Act, sections 30 through 33 in Part IV and Part V address these matters.

3. Section 4.020(1) of the Regulations to the Alberta Act. Section 27(1) of the Saskatchewan Act indicates that the drainage unit for an oil well is considered to be one legal subdivision however specific regulations passed in respect of various parts of the province alter this spacing unit size to be either a full quarter section (160 acres) or two legal subdivisions ( 80 acres).

32. Section 4.020(3) of the Regulations to the Alberta Act and s. 27(2) of the Regulations to the Saskatchewan Act. 


\section{Alberta}

The Alberta position with respect to spacing, which is administered by the ERCB, ${ }^{33}$ has been to adapt the existing regulatory regime to spacing units for horizontal wells. The ERCB currently requires that "horizontal wells are subject to the same licensing provisions as other wells. ${ }^{134}$ Further, the ERCB stipulates that "horizontal wells and horizontal completions in existing wells are also subject to the same Drilling Spacing Unit (DSU) considerations as conventional vertical wells. ${ }^{135}$ In effect, the entire horizontal borehole within the producing formation must be within the target area for the spacing unit unless specifically exempted by a special spacing unit provision. The implications of the horizontal borehole falling outside the target area are that all of the production from the well will be subject to an off target penalty on the basis of, in the case of a traditional drilling spacing unit, the point of furthest departure from the target area or, in the case of a special drilling spacing unit prescribing minimum interwell distances, the point of closest approach to other surrounding wells. ${ }^{36}$

The "target area" defined in paragraph 1.020(2)29 of the Alberta Regulations is even smaller than the spacing unit itself. The normal target area in Alberta for an oil well having a spacing unit of 160 acres is a square having sides 200 metres from the sides of the quarter section in question ${ }^{37}$ and for a 640 acre gas well, a square having sides 300 metres from the sides of the section in question. ${ }^{38}$ The effect of the ERCB's approach is that if one metre of a 300 metre horizontal borehole is outside the target area for the drilling spacing unit then all of the production from that well is subject to an off target penalty.

Rather than setting up special rules to deal with the drilling of horizontal wells across traditional spacing unit boundaries, the ERCB proposes that, to the extent horizontal wells are not accommodated by the existing regulations, they be dealt with on a case by case basis by way of individual application. Draft \#5 of Proposed ERCB Information Letter IL 90- (the Draft Information Letter) is intended to update and expand the information relating to horizontal wells contained in the earlier ERCB Information Letter IL 87-12. In the Draft Information Letter, the ERCB indicates that in its opinion special drilling spacing units best accommodate proposals for the drilling, completing and producing of horizontal wells. Applications for special drilling spacing units are governed by the Alberta Regulations. ${ }^{39}$ While Attachment II to the Draft Information Letter provides some guidelines about what the ERCB will find acceptable in terms of special drilling spacing units for horizontal wells, it is important to note that an application under section

The ERCB is constituted in accordance with the provisions of the Energy Resources Conservation Act, R.S.A. 1980, c. E-11, and is the regulatory body charged with administering the Alberta Act. ERCB Information Letter IL 87-12 dated 3 November 1987.

Ibid.

Ibid.

Supra, note 23, s. 4.020(1).

Ihid. s. 4.020(3).

Ibid. s. 4.303. 
4.030 of the Alberta Regulations requires the submission of significant information and a public hearing or publication of notice. ${ }^{40}$

Publication of notice is likely to attract attention from any competitive offsetting working interest owners who may dispute a horizontal well proposal, resulting in a public hearing. The requirement for public hearings or publications of notice as contemplated in the Alberta Regulations suggests that attempts to obtain approval for larger than normal spacing units to facilitate horizontal drilling could become a costly and time consuming process. This would be particularly true if competitive offsetting working interest owners appear at these hearings represented by counsel in an attempt to protect what they perceive to be their correlative rights.

Since horizontal drilling technology is continuing to evolve, operators that have incurred significant expenses to develop horizontal drilling expertise will undoubtedly consider the information they have obtained and the expertise they have developed to be valuable. As public hearings do not lend themselves to maintenance of confidentiality, some operators may be discouraged from pursuing a horizontal well opportunity in light of the need for an application for a special drilling spacing unit.

It is also suggested in the Draft Information Letter that where larger areas of land having common ownership of mineral rights are involved, such as unitized formations, the ERCB may consider the use of miscellaneous orders or infill orders as an alternative to a special spacing unit application. In any event, an application to the ERCB would still be required which may give rise to a public hearing.

The Independent Petroleum Association of Canada (IPAC) has suggested that, while significant regulation changes are not required, some modification will be necessary to account for the unique character of horizontal wells, particularly in competitive operations in the same pool. ${ }^{41}$ IPAC has made recommendations respecting the establishment of a transitional set of rules within the existing regulatory framework to permit the gathering of information and experience without disadvantaging existing operators.

One of IPAC's recommendations regarding spacing is that where the target area adjoins a competitive lease line a buffer zone equal to 100 metres or $1 / 2$ of the drilling spacing unit size dimension, whichever is less, should be introduced. No portion of a horizontal well would be allowed to be completed within the buffer zone. The Draft Information Letter, although stating that buffer zone requirements have not been fixed by the ERCB, does suggest that a 100 metre buffer zone should apply to horizontal wells on the basis that:

The [ERCB] sees merit in an additional buffer zone criteria of that nature for horizontal wells for an interim period of time to permit industry the opportunity to obtain horizontal well performance data and to better understand possible lease line drainage issues. ${ }^{42}$ 
As far as combining contiguous traditional spacing units pursuant to approvals granted under applications for special drilling spacing units for horizontal wells, IPAC has recommended that along competitive lease lines, they should be allowed to be joined in a north/south and east/west direction. ${ }^{43}$ Attachment II to the Draft Information Letter sets out the determination of the target area upon combination of traditional spacing units and, as indicated, also provides some illustrative special drilling spacing unit configurations.

It has also been suggested that the use of the concept of a "holding" under the Alberta Act can be used to permit horizontal wells covering more than one traditional spacing unit. ${ }^{44}$ The term "holding" is defined in clause 1(k.01) of the Alberta Act as "an area established as a holding pursuant to the regulations." Section 10(l) of the Alberta Act then gives the ERCB the power to make regulations providing for the establishment of holdings and prescribing the rules to be applied within holdings. Sections 5.190 to 5.220 of the Alberta Regulations essentially permit the ERCB to suspend the application of the normal regulations in any area it designates as a holding. An important restriction on the use of holdings for permitting horizontal wells is that the holding must, as required by section 5.200 of the Alberta Regulations, contain only whole, contiguous drilling spacing units of common ownership. The designation of an area as a holding is also at the discretion of the ERCB and it may be reluctant to so designate where it could affect competitive interests.

In deciding whether to permit special spacing units for horizontal wells in areas of competitive ownership, the ERCB is invariably going to be confronted with issues of equity as between competing mineral owners. Horizontal well proponents will argue the benefits as outlined earlier in this paper, while the owners of neighbouring spacing units will argue the detriments. Although the ERCB has the ability to make judgments as to the technical soundness of applications laid before it, we believe that ultimately the policy as to whether horizontal drilling is to be encouraged or not in Alberta may become the overriding factor. In the absence of a clear policy direction from the Alberta government, the ERCB may find some of these decisions difficult to make, the net effect of which may be to deter industry from pursuing this new technology in Alberta.

\section{Saskatchewan}

The Saskatchewan Department of Energy and Mines (SEM) has taken a different approach than the ERCB in Alberta. The Minister of Energy and Mines (the Minister) is charged with administering the Saskatchewan Act and through the Saskatchewan Task Force Report clearly acknowledges the necessity to combine existing drainage units to accommodate horizontal wells. ${ }^{45}$ Although specific regulations have not yet been drafted,

Ibid.

4. R. Hatala, "Horizontal Drilling: Challenges to Innovation" Speech to the Canadian Association of Petrolcum Landmen, 9 April 1991 at 13.

45. This task force was formed in September of 1990 to review the existing regulatory regime and current horizontal well issues and make recommendations to the Minister on longer term policies for horizontal well development in Saskatchewan. The task force was comprised of representatives of 
the Saskatchewan Task Force Report indicates that the objective should be to allow horizontal well drainage areas to consist of all the existing drainage units (that were established for vertical wells) that the horizontal section transverses and those from which drainage is likely to occur. ${ }^{46}$ The proposal in the Saskatchewan Task Force Report is clearly more flexible than the position of the ERCB in Alberta, however, it requires common working interest and mineral ownership in the combined drainage units, whether by pooling, unitization or otherwise before any such new drainage units would be established.

At the time of striking the task force, the Minister was involved in a law suit respecting, among other things, the exercise of his discretion in the establishment of a drainage unit for a horizontal well in light of the provisions of the Saskatchewan Act and the regulations thereunder (the Saskatchewan Regulations). ${ }^{47}$ The case was Kennibar Resources Ltd. v. The Minister of Energy and Mines for the Province of Saskatchewan and Gulf Canada Resources Limited. ${ }^{48}$ Gulf Canada Resources Limited (Gulf) had applied to the Minister for permission to drill and develop a horizontal well in a particular pool which was to transverse certain drainage units and Gulf also requested good production practice (GPP) status for the proposed well in order to regulate its own production levels without the restrictions common to neighbouring vertical wells. ${ }^{49}$ The Minister gave public notice of the Gulf application and requested objections. Kennibar Resources Ltd. (Kennibar) responded to the Minister's notice supporting Gulf's application to drill the horizontal well but objecting to Gulf's request that the well be accorded GPP status. Kennibar's concerns were that assignment of GPP status to the well would allow Gulf to unfairly capture petroleum substances in the same pool from under offsetting lands via the rule of capture and hence contravene the provisions of section 3(c) of the Saskatchewan Act which requires the SEM to "protect the correlative rights of each owner." ${ }^{\text {50 }}$

The Minister issued an order approving Gulf's application and granting GPP status to the proposed well. The order did, however, in partial response to Kennibar's concerns, reduce the horizontal length of the proposed well in order to provide a greater distance between the producing portion of the well and Kennibar's lease lines and indicated that SEM would monitor production from surrounding vertical wells to determine whether inequitable drainage was occurring whereupon GPP status would be rescinded and a specific allowable would be assigned to the horizontal well. Kennibar applied to the Minister pursuant to section 50 of the Saskatchewan Act for a hearing by the Oil and Gas Conservation Board (the Board) in respect of the proposed Gulf well being accorded GPP

SEM, IPAC, the Canadian Petroleum Association (CPA) and the Small Explorers and Producers Association of Canada (SEPAC).

Supra, note 2 at 9.

Oil and Gas Consenvation Regulations. 1985, R.R.S., c. O-2, Reg. 1.

88 Sask. R. 35. (hereinafter Kennibar).

See text accompanying notes 68 to 70 .

See text accompanying notes 15 to 29 . 
status." Without granting Kennibar a hearing, the Minister rescinded his original order and replaced it with a second order containing some minor modifications. Kennibar made a second application to the Minister for a hearing by the Board again in respect of the GPP status assigned to the proposed well under the second order. Kennibar's second request for a hearing was denied by the Minister.

The Gulf horizontal well was drilled and put on production in early September 1990. Production rates were substantially in excess of the estimate contained in Gulf's original application and four to five times greater than those of vertical wells in the immediate vicinity.

The formal questions put to the Court for resolution were of a fairly technical legal nature, however, very simply stated, Kennibar felt the Minister: (i) erred in granting the order in light of certain provisions of the Saskatchewan Act; (ii) exercised his discretion in such a fashion that he exceeded or lost jurisdiction to grant the order; and (iii) did not adhere to the principles of natural justice and procedural fairness under the common law in making his decision to grant the order which effected the rights, privileges and interests of Kennibar.

One of the arguments made by Kennibar was that the Minister, in approving Gulf's horizontal well with GPP status, acted in a fashion inconsistent with the purposes of the Saskatchewan Act set out in s. $3^{52}$ since he failed "to protect the correlative rights of" ${ }^{\text {"53 }}$ Kennibar and failed to "enable each owner to obtain his just and equitable share of the allowable production of any pool. ${ }^{5.54}$ The Court dispensed with this issue on the basis that it was not possible for it to make a finding as to whether or not drainage had occurred with respect to Kennibar's offsetting lands due to the conflicting evidence put before it. As a result, the Court was unable to conclude that drainage had occurred and therefore there was no interference with the correlative rights of Kennibar and further, no interference with Kennibar's ability to obtain its just and equitable share of production from the pool. The result is that the Minister's order was not inconsistent with the provisions of the Saskatchewan Act and hence by granting the order, the Minister did not commit an error in respect of s. 3 of the Saskatchewan Act.

It is interesting to note that the effect of this conclusion is that correlative rights continue in Canada to be a creation of statute with no foundation in the common law. Therefore, the rule of capture continues to be predominant as contemplated in the Borys case subject only to compliance with applicable legislation.

The Board is contemplated to be established in accordance with s. 7 of the Saskatchewan Act and is charged with exercising the powers and performing the duties conferred and imposed upon it in the Saskatchewan Act, and with inquiring into any matter referred to it by the Minster and making a report thereon. Infra, note 61 .

52. Section 3 of the Saskatchewan Act, supra, note 21. Also sec supra, note 22.

si. Ihid. s. 3(c).

ss. Ihid. s. 3(d). 
The second argument of Kennibar was that the Minister, by assigning Gulf's horizontal well a drainage unit comprising four legal subdivisions, violated $5.25^{55}$ of the Saskatchewan Act. Gulf's position was that the size of a drainage unit is of no consequence to an offsetting working interest owner in terms of correlative rights on the basis that such rights are effected only if a restriction on production by the offsetting owner occurs as a result of the size of the assigned drainage unit. Gulf further argued that s. $26^{56}$ of the Saskatchewan Act, should be read in conjunction with s. 25 with a view to permitting the Minister to effectively size drainage units to restrict the number of wells in a pool in the interests of efficiency and economy given the ability of those wells to efficiently drain the pool. Those sections read as follows:

25. The minister shall by order establish drainage units of uniform size and shape for a field or pool, provided that, where he deems it to be necessary by reason of differences in the character of the formation, the minister may divide a pool into zones and establish drainage units for each zone. and the drainage units in a zone may differ in size and shape from those in another zone.

26. The size and shape of drainage units shall be such as will result in the efficient and economical development of the field or pool as a whole, and the size shall not be smaller than the maximum area that can be efficiently drained by one well.

Despite Gulf's arguments, the Court came to the conclusion that, .".. by virtue of s. 25 of the [Saskatchewan] Act, it is mandatory for the Minister, by order, to establish drainage units which are uniform in size and shape for each pool. In compliance with this mandatory direction, the Minister, in respect of this "pool," ordered the uniform size and shape of the subject drainage unit to be comprised of one legal subdivision." 57 The Court also concluded that this position was consistent with s. 27 of the Saskatchewan Regulations which sets out the size of drainage units.

In effect the Court's conclusion with regard to the second argument by Kennibar, was that the Minister committed an error in interpreting the Saskatchewan Act by assigning a drainage unit of four legal subdivisions to the Gulf well in the face of a previous order by the Minister, respecting the same pool which fixed drainage units for the drilling and completion of oil wells at one legal subdivision.

On Kennibar's third argument that it had not received a fair hearing contemplated under s. 50 of the Saskatchewan Act, ${ }^{58}$ the Court concluded that the Minister ought to have adhered to the common law principles of natural justice and procedural fairness and that he "should not have dismissed without a fair hearing in which [Kennibar] had the opportunity to fully place its arguments before the Minister or the Board." ${ }^{\text {59 }}$ In fact, the Board had not been in existence for many years and despite that, the Court indicated that

Bill 73 would amend the Saskatchewan Act by repealing, among others, s. 25. Infia, note 61. Bill 73 would amend the Saskatchewan Act by repealing. among others, s. 26. Infra, note 61 . Supra, note 48 at 15.

Bill 73 would amend the Saskatchewan Act by repealing, among others, s. 50. Infra, note 61 . Supra, note 48 at 23. 
the Minister was placed in a position where he must either have a Board in place to hold hearings or grant a hearing directly to Kennibar.

The outcome of the case was that the Court quashed the Minister's order, the effect of which is that Gulf cannot produce the well until such time as lawful approval is obtained. Gulf appealed the decision to the Saskatchewan Court of Appeal which, in a judgment delivered 18 April 1991 supported the lower Court's conclusion purely on the basis that the Minister failed to provide Kennibar with a hearing in accordance with the principles of natural justice and procedural fairness.

The ultimate effect of this case is that the Saskatchewan Act and the Saskatchewan Regulations are not adequate to deal with the drilling of horizontal wells and the development of such technology and hence, will need to be changed. The Court acknowledges this fact in the original decision where it indicated:

It is clear from the arguments advanced by all parties that horizontal drilling is a relatively new technology in this province. The legislation in place does not contemplate issues arising from this technology and the problem lies in the failure of the [Saskatchewan] Act and the [Saskatchewan] Regulations to kecp pace with the new advances in the industry.

As indicated earlier, the Saskatchewan legislature completed the first reading of Bill 73 which would amend the Saskatchewan Act in such a fashion to permit the Minister the discretion to deal with situations such as that arising in the Kennibar case and to specifically acknowledge the horizontal well technology. ${ }^{61}$ The writers understand that appropriate regulations will also be prepared upon amendment of the Saskatchewan Act which will address many of the issues raised by the Saskatchewan Task Force Report.

\section{ALLOWABLES}

In both Alberta and Saskatchewan, allowable production rates for petroleum substances on a provincial basis are determined by the ERCB and SEM respectively. These

w. Ihid. at 15.

at. Supra, note 1. The proposed amendments to the Saskatchewan Act in Bill 73 provide the Minister with very broad and flexible power through the introduction of ss. 6.1, 6.2 and 6.3. These sections will provide the Minister with exclusive jurisdiction over all matters respecting the power, authority and discretion conferred on him under the Saskatchewan Act and allow him to rescind, amend, alter, suspend or reconsider any decision or order he has made, any approval he has granted or any permit or license he has issued. Additionally, the draft provisions indicate there is no appeal from an order or decision of the Minister and that all decisions, findings and orders of the Minister are final and conclusive and are not reviewable in any court of law. Clearly the amendments in Bill 73 are in part a response to the outcome of the Kennibar case.

Additionally, s. 7 of the Saskatchewan Act which sets out the authority for the establishment of the Oil and Gas Conservation Board, is intended to be repealed and replaced with extensive provisions in new ss. 7 through 7.9. These provisions greatly expand upon the right, powers and procedures of the Board and specifically include a provision, in s. 7.2(1) whereby, in the case the Board has not been established or where the Minister considers it advisable, the Minister may direct an official of his department to carry out the powers conferred upon the Board. 
provincial allowables are allocated in an equitable manner among the pools of petroleum substances identified in each province for the purpose of giving each owner of a working interest in each well "the opportunity of producing or receiving his just and equitable share" 62 of crude oil produced from such pools. Further, "in the interests of conservation or the protection of correlative rights, ${ }^{6.3}$ the ERCB and SEM can prescribe a factor or other rules relating to the production from particular wells. ${ }^{\text {(t) }}$ In effect, the regulation of production rates is continually changing and is dependent upon, among other things, provincial guidelines and specific pool production capabilities. Both provinces have specific regulations and ministerial orders or policy guidelines relating to complicated calculations for determining allowable production rates of crude oil on a pool by pool and well by well basis. ${ }^{65}$

It is possible, in both Alberta and Saskatchewan for a well or a particular pool to be produced in accordance with GPP as opposed to in compliance with a specific allowable production rate. The Alberta Regulations define this term as follows:

"GPP" means production of crude oil or raw gas at a rate

$$
\text { not governed by a base allowable, but }
$$

limited to what can be produced without adversely and significantly affecting conservation, the prevention of waste, or the opportunity of each owner in the pool to obtain his share of production. th $^{\text {wh }}$

In Saskatchewan the term GPP has never been defined by legislation however the Saskatchewan Task Force Report proposes that the following definition be incorporated into the Saskatchewan Regulations:

\footnotetext{
"GPP" means production of oil and gas from a well at a rate not governed by an allowable but limited to what can, on the basis of technical parameters governing each well, be produced without adversely and significantly effecting the ultimate recovery of oil and gas or the opportunity of other owners to obtain their share of production from the reservoir. ${ }^{\text {t? }}$
}

The regulatory bodies in these provinces have again dealt with the application of the issue of allowables to horizontal well technology on a different basis.

Section 22(c) of the Alberta Act and s. 23 of the Saskatchewan Act. Bill 73 would have the effect of repealing s. 23 of the Saskatchewan Act.

Supra, note 23, s. 10.120 .

By virtue of s. 3 of the Saskatchewan Act.

Reference is made to a series of ministerial orders which are issued and published regularly in Saskaltchewan and Alberta, in accordance with and pursuant to the Alberta Regulations and the Saskaltchewan Regulations.

Alberta Regulations, s. 1.020(1)9.

Supra, note 2 at 7. 
1. Alberta

The ERCB, in the Draft Information Letter, indicates that there are no special provisions in existence with respect to horizontal wells and that allowables are to be determined on the same basis as for conventional vertical wells. The Draft Information Letter does go on to acknowledge that horizontal wells may exhibit production characteristics that may entitle them to different allowables or GPP treatment. IPAC has made certain recommendations in its discussion paper which relate to competitive versus non-competitive situations. ${ }^{68}$ In a non-competitive situation, where equity is not a concern, IPAC has recommended that GPP status be afforded horizontal wells automatically at the time of licensing. The ERCB in the Draft Information Letter suggests that it will look favourably on proposals for special allowable or GPP status being afforded horizontal wells "provided they directionally favour conservation benefits and there is an absence of equity concerns." ${ }^{69}$

With respect to competitive situations, the ERCB has invited industry to submit proposals for consideration in developing production rate limitations respecting horizontal wells. IPAC has suggested a concept of "vertical equivalence" which relates a horizontal well to the number of vertical wells that would be required to drain the same area. "The main principle behind vertical equivalence is that since existing production regulations were basically designed for vertical wells, it is logically appealing to consider horizontal wells in the same fashion." ${ }^{70}$ This concept is, according to IPAC, consistent with the existing ERCB practice and would require ERCB approval for the appropriate spacing unit and target area with respect to which the vertical equivalence of a horizontal well, and hence the allowable, would be based. IPAC's recommendation indicates that the minimum allowance for horizontal wells should equal the total minimum allowance that would have been assigned by the ERCB if single vertical wells were to be drilled in the drilling spacing units which are combined for purposes of creating the drilling spacing unit for the horizontal well in question.

It is clear that to the extent that the $A$ !herta regulatory regime does not accommodate the new technology, the interest which exists in horizontal well drilling will wane. Again the current position of the ERCB is to address the awarding of the appropriate allowable or the granting of GPP status on an application by application basis. This may give rise to inconsistency in treatment and may not encourage development of the technology.

\section{Saskatchewan}

The Saskatchewan Act and Saskatchewan Regulations do not specifically provide for allowables relating to horizontal well technology however, as in Alberta, sufficient flexibility exists for setting allowables on a case by case basis, provided of course that the Minister grants all interested parties with an appropriate hearing in respect of any complaints as contemplated in the Kennibar decision. The Saskatchewan Task Force 
Report however, concluded that a system was necessary for applying allowables to horizontal wells.

In non-competitive situations, the Saskatchewan Task Force Report recommended that GPP should be granted and as indicated have recommended a definition for GPP ${ }^{71}$ substantially similar to that in the Alberta Regulations. It is interesting to note that the task force also suggested that SEM might require justification for actual production rates even though GPP status is granted.

In competitive situations, the task force recommended that GPP be granted for heavy oil wells unless setbacks and buffer zones are violated. With regard to non-heavy oil, GPP is proposed to be granted only if no valid objections are received after public notice of a proposed allowable for a particular horizontal well or if written consents are received from all potentially affected parties.

The Saskatchewan Task Force Report addresses specifically the need to differentiate between, and makes a suggestion for determining, competitive versus non-competitive situations. In the case of heavy oil, the recommendation is that all horizontal heavy oil wells will be deemed to be non-competitive provided they adhere to setback distances. In the case of non-heavy oil areas, the task force suggests that an appropriate definition would be that a competitive situation exists:

where there is diversely owned land (mineral and/or working interest ownership) within 500 metres from any portion of the productive horizontal section of the horizontal well. The diversely owned land ... must be part of a drainage unit containing a productive well. A productive well is an oil well that, in the opinion of the Minister, is capable of producing commercial quantities of oil on a sustained basis."

The concepts of "block allowable," "recovery multiplier" and "adjusted block allowable" are also introduced in the Saskatchewan Task Force Report. In essence the block allowable is intended to be the sum of allowables for all vertical wells (or potential vertical wells) in the required spacing or drainage units combined to form the block where the horizontal well is to be drilled. This concept is similar to that of "vertical equivalence" proposed by IPAC ${ }^{73}$ and is intended to provide consistency between horizontal blocks and neighbouring vertical wells. The block allowable is intended to represent a minimal allowable and would be adjusted to recognize increased recovery from horizontal wells. That adjustment factor is known as the recovery multiplier and is based on the productive length of the horizontal well. The maximum recovery multiplier is two and the adjusted block allowable is the block allowable multiplied by the recovery multiplier.

Further, the Saskatchewan Task Force Report suggests that additional rules will be necessary to govern the interplay of multiple horizontal wells and surrounding vertical wells as well as for applying appropriate penalty factors where minimum distance

\footnotetext{
71. This proposed definition of GPP is set out in the text accompanying note 67.

72. Supra, note 2 at 7.

73. Supra, note 41.
} 
restrictions are violated. However it is important to note that the approach that will probably be taken by SEM is to draft a specific set of rules and regulations relating to the drilling and production of horizontal wells in that jurisdiction. It is probably a safe conclusion that whatever final amendments are made to the Saskatchewan Act and the Saskatchewan Regulations to create that set of rules, SEM will want to retain all necessary flexibility and discretion to deal with specific situations and will undoubtedly offer all complaining parties an appropriate hearing.

\section{POOLING AND UNITIZATION}

Both the Alberta Act and the Saskatchewan Act have provisions dealing with the pooling of lands to constitute a spacing unit and with the unitization of a number of spacing units in respect of a particular common reservoir for purposes of producing petroleum substances more efficiently. It is interesting that the framework of Part 12 of the Alberta Act provides a mechanism for voluntary unitization in which the ERCB's role is to "encourage efforts initiated by owners of oil and gas interests in any pool to consolidate, merge or otherwise combine their interests for the purpose of accomplishing the more efficient and more economical development and production of the oil and gas resources of the pool." ${ }^{74}$ Further, the provisions relating to pooling ${ }^{75}$ in the Alberta Act contemplate forced pooling where a working interest owner who is unable to reach agreement with other working interest owners to form a spacing unit may apply to the ERCB for an order directing that all parcels of land within the spacing unit be operated as one unit. In practice, the ERCB takes a passive role in unitization and a fairly passive role in pooling, except on rare occasions to facilitate production through forced pooling orders. In Alberta it is also possible to apply for a special pooling order under the Alberta Regulations which is intended to accommodate unique spacing requirements. An example of such a situation would be where established pool boundaries straddle existing lease lines.

In Saskatchewan the pooling provisions are relatively similar to those in Alberta and facilitate the drilling of additional wells by virtue of forced pooling orders. Again situations arise where such wells would not otherwise be drilled in light of the failure to reach a voluntary pooling arrangement among all working interest owners. However, the unitization provisions ${ }^{76}$ provide that the Minister may, on "his own motion ... order that a hearing be held by the [B]oard to consider the need for the operation as a unit of an entire field or pool."${ }^{.77}$

Given the discretion and ability of the Minister in Saskatchewan to initiate the unitization process, ${ }^{78}$ it is apparent that horizontal drilling on an infill or developmental

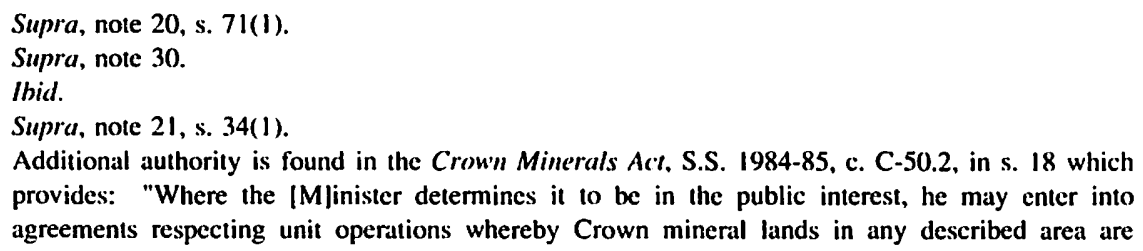


basis may give rise to additional unitization, whether in competitive situations or not. In Alberta, on the other hand, working interest owners, whether of horizontal or vertical wells accessing the same reservoir, will have to be in agreement to implement unitization.

\section{E. CROWN OFFSET OBLIGATIONS}

Since larger spacing units are being formed or are contemplated to be formed to accommodate horizontal drilling, working interest owners of surrounding lands will need to monitor and abide by the offset drilling obligations that will arise upon the drilling of a horizontal well. Obviously if a spacing unit for a horizontal well is comprised of two or more drilling spacing units that would otherwise have been used to drill vertical wells, the drilling of the horizontal well has the potential to trigger more offset obligations than if a vertical well had been drilled on only one of the vertical drilling spacing units. Offset obligations arise in respect of both crown ${ }^{79}$ and freehold ${ }^{80}$ minerals. A discussion of this issue as it relates to freehold leases appears later in this paper.

The offset drilling obligations in Alberta and Saskatchewan which arise under the provincial regulations, ${ }^{81}$ require that a lessee of crown mineral rights shall, where petroleum substances are being obtained from a formation to which the lease applies in a spacing unit adjoining the subject crown lands, within 90 days after receiving a written request from the Minister in Saskatchewan or no later than $\mathbf{9 0}$ days after the date from which production has commenced in Alberta:

commence drilling an offset well;

(ii) pay compensatory royalty on the basis of production from the well creating the offset obligation; or

(iii) surrender the spacing unit on which the offsetting well is required, in its entirety or in respect of the producing zone in the well creating the offset.

Generally, offset drilling obligations are in respect of spacing units which laterally adjoin the spacing unit of the producing well giving rise to the offset obligation. ${ }^{82}$ Given

merged, consolidated or integrated with other Crown mineral lands or with mineral lands owned by any other person, or both, in the described area for the purpose of being operated as a unit ...." In Alberta, offset drilling obligations arise under ss. 21 and 22 of the Petroleum and Natural Gas Agreements Regulation, Alta. Reg. 188/85, which regulations are promulgated under and pursuant to the authority contained in the Mines and Minerals Act, R.S.A. 1980, c. M-15. In Saskatchewan. offset drilling obligations arise under s. 52 of the Petroleum and Natural Gas Regulations, 1969, Sask. Reg. 8/69, which regulations are promulgated under and pursuant to Crown Minerals Act, S.S. 19841985, c. C-50.2.

xi. Offset drilling obligations with respect to freehold mines and minerals arise as a term of contract contained in the specific freehold lease.

x. $\quad$ Supra, note 79.

x2. In Saskatchewan, s. 52(2) of the Petroleum and Natural Gas Regulations, 1969, Sask. Reg. 8/69, as amended, designates lateral offset locations in the case of 10,40, 160 and 640 acre spacing and diagonal offset locations in the case of 20,80 or 320 acre spacing. 
that spacing unit sizes for horizontal and vertical wells have been and will undoubtedly continue to be different, consider, for purposes of this discussion, the following:

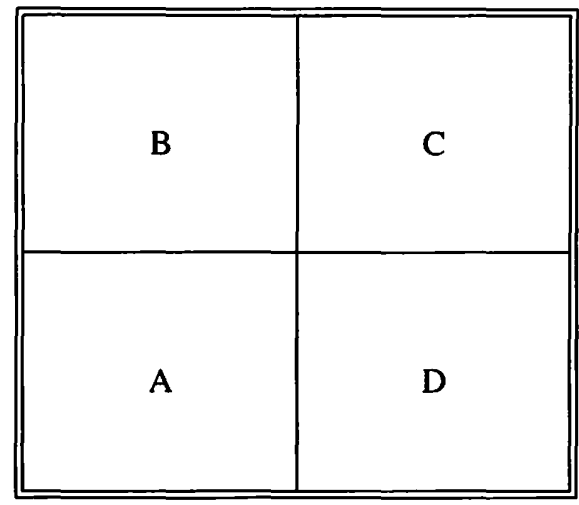

Assume that each of parcels A, B, C and D constitute a traditional spacing unit for a vertical well, but that parceis $A$ and $B$ combined will constitute a spacing unit for a proposed horizontal well. In the case of vertical wells, a freehold well producing on parcel A would trigger, assuming parcels B, C and D are crown lands, offset drilling obligations on parcels $B$ and $D$ but not on parcel $C$ as parcels $A$ and $C$ are not laterally adjoining.

Now assume that parcels A and B comprise the spacing unit for horizontal well and such a freehold well is drilled and completed for production on parcel $A$ with the horizontal well bore extending through parcel $A$ into parcel $B$. As both parcels $C$ and D laterally adjoin parcels $A$ and $B$, under the regulations an offset drilling obligation arises in respect of both parcels $C$ and $D .^{83}$

Now consider the situation where a freehold horizontal well is spudded at a location on parcel $A$ of the spacing unit comprising parcels $A$ and $B$, however, that well has to be abandoned due to completion problems and is turned into a vertical well completed in parcel A alone. It is not clear as to whether or not the drilling of this well on parcel A still gives rise to an offset obligation with respect to parcel C. It seems logical that the spacing unit for the proposed horizontal well comprising parcels $\mathrm{A}$ and $\mathrm{B}$ would, in these circumstances, be reduced in respect of the ultimate well to that of parcel A. However, we suspect that an application for such reduced spacing would have to be made to either the ERCB or SEM, as the case may be.

\section{ROYALTIES AND INCENTIVES}

The royalty schemes for horizontal wells provide a dramatic illustration of the differences in attitude to horizontal wells between Alberta and Saskatchewan. Alberta provides no specific incentives for horizontal wells unless the well qualifies in the general

xi. Obviously such an offset obligation also arises in respect of the laterally adjoining spacing units on the other three sides of parcels $A$ and $B$. 
category of being an experimental scheme, in which case a reduced royalty is available. Despite some recent changes, Alberta, in some cases, still discourages the drilling of horizontal wells by the nature of its royalty and incentive schemes. Saskatchewan, on the other hand, promotes the use of horizontal wells by way of favourable royalty and tax treatment. Some of the details of the two schemes are discussed below.

\section{A. ALBERTA}

\section{Experimental Schemes}

Initially royalty relief was available in Alberta for horizontal wells if they could be classified as an experimental scheme. If a horizontal well qualifies as an experimental scheme then production from that well will be subject to a $5 \%$ royalty. To date the majority of horizontal wells drilled in Alberta have had experimental scheme status but this status is less and less likely to be awarded in the future. The Alberta Regulations, define an "experimental scheme" as:

a scheme approved by the Board [ERCB] and using methods that are untried or unproven in the particular application. $^{\mathrm{s.4}}$

In ERCB Information Letter IL OG 78-12 the ERCB discusses the criteria that it feels must be met in order for them to approve an experimental scheme. There are two of these criteria that are now causing problems in getting horizontal wells classified as experimental schemes. Firstly, the ERCB requires that the scheme be distinct from previous tests. IPAC ${ }^{85}$ and others have attempted to argue that in these early stages of horizontal well development the first horizontal well into any reservoir is an experiment. The ERCB has so far taken a more restricted view of the distinction requirement and the number of wells that meet this criteria is expected to decrease in the future as more horizontal wells are drilled.

Secondly, the ERCB requires that "the broad economics of this scheme, when considered with the technical uncertainties, do not suggest immediate commercial viability." ${ }^{\text {"86 }}$ Simply put, the horizontal well cannot be commercially viable if it is to qualify as an experimental scheme. Unfortunately for the purposes of this requirement, but fortunately for the future of horizontal drilling, the decrease in costs of horizontal drilling and the benefits that have been obtained make it less and less likely that a company is going to propose a horizontal well that is not going to be a viable commercial project.

In summary, it appears that the use of experimental scheme status to reduce royalties is a rapidly disappearing, if not extinct, phenomenon in Alberta.

\footnotetext{
Su. Supra, note 23, s. $1.020(2) 6$.

*s. Supra, note 41 .

*6. ERCB Information Letter IL OG 78-12.
} 
2. Non-Experimental Wells

In Alberta a horizontal well is subject to the same royalties as any other well if it has not been approved as part of an experimental scheme and subject to certain exceptions in the case of oil wells as discussed below. These royalties are significantly higher than they would be for the same horizontal well drilled in Saskatchewan. Until recent amendments the method of calculation of oil royalties in Alberta could in fact provide a disincentive for horizontal wells.

Alberta oil royalties are production rate sensitive. In other words, the higher the rate of production the higher the percentage royalty the government takes on that production. Since one of the characteristics of horizontal wells is their high production rates, as compared to vertical wells, this results in a higher percentage royalty being levied on the production from the horizontal well.

To use a simple example, suppose that a single horizontal well can drain two spacing units. A single horizontal well costs two times as much to drill as the vertical well but it can produce twice the rate of a vertical well. Even though the investment is the same and the amount of production is the same, the production from the horizontal well is subject to a greater percentage royalty than the same combined production from the two vertical wells. This disincentive to horizontal drilling could have caused a significant loss to the province over time if, as suggested by proponents of horizontal drilling, the ultimate oil recovered by a single horizontal well will be greater than the oil ultimately recovered by the two vertical wells.

On April 2, 1991 the Alberta Government announced some changes to the royalty structure for horizontal wells for a 2-year period from December 31, 1990 to January 1, $1993 .^{87}$ The change is essentially to adopt a vertical equivalency approach by reducing the productivity factor that goes into the calculation of the oil royalty depending on the number of vertical wells "replaced" by the horizontal well. This is an attempt by the Alberta government to ameliorate the penalization of horizontal wells that was caused by the sliding scale oil royalties. These recently announced changes have no application to gas royalties and still leave the Alberta royalties significantly higher than the Saskatchewan royalties on the same horizontal oil well.

\section{Incentives}

Government incentive programs which were designed with vertical wells in mind and awarded on a well by well basis can also act as a disincentive to the use of horizontal wells in place of vertical wells. For example, the Alberta Deep Gas Royalty Holiday Program ${ }^{88}$ provides for a sliding scale of royalty relief depending on the depth of a well and starting at 2500 metres. The amount of royalty relief to which a well is entitled is 1991 at 3.

xx. Alta. Reg. $16 / 74$, s. 2.18 . 
determined by multiplying the vertical depth of the well times a factor specified in the regulations. Each qualifying well is entitled to the royalty holiday.

Even if a horizontal well is capable of replacing two vertical wells and producing as much or more gas than the two vertical wells, the horizontal well still only receives one royalty holiday while each vertical well would be entitled to its own royalty holiday. Since the person drilling the well receives twice the royalty if he drills two vertical wells this results in a powerful incentive to drill the vertical wells even if the amount of gas ultimately recovered by the horizontal well is greater than the amount that would be recovered by two vertical wells.

\section{B. SASKATCHEWAN}

Until March 31, 1991 horizontal wells in Saskatchewan were treated as enhanced oil recovery projects. This meant that they were subject to a cost and revenue sensitive royalty scheme which allowed the company drilling the well to recover its investment before being subject to significant royalties or taxes. This scheme was obviously preferable to the non-experimental Alberta royalties from the standpoint of proponents.

For horizontal wells with a finished drilling date on or after March 31, 1991 all nondeep horizontal wells (above 1700 metres and the Mississippian formation) on Crown land will pay a $5 \%$ royalty (less the $1 \%$ Saskatchewan Resource Credit) on the first 12,000 cubic metres of production. Any production above 12,000 cubic metres will be subject to normal royalties. Non-deep horizontal wells on freehold lands will not be subject to the freehold oil tax until after the first 12,000 cubic metres of production. Deep horizontal wells will be subject to the same 3-year (development wells) and 5-year (exploratory wells) royalty holidays as vertical wells. This new Saskatchewan royalty and tax scheme is still more favourable than the Alberta non-experimental scheme from the standpoint of horizontal well proponents and will continue to be a strong incentive to drill horizontal wells in Saskatchewan rather than Alberta.

\section{INDUSTRY AGREEMENTS}

The advent of horizontal drilling technology not only requires the specific attention of the regulators with respect to the items raised earlier in this paper, but industry as well must be attuned to the application of what have become "standard" or "usual" forms of agreements to this type of drilling. This paper is not intended to provide an exhaustive list of potential problems and pitfalls that may arise when using standard industry forms of agreement with regard to horizontal well drilling but addresses a number of common examples.

\section{A. OPERATING AGREEMENTS}

Where the ownership of the formation to be accessed by a horizontal well is by the same working interest owners in the same percentage interests throughout the entire spacing unit for the horizontal well, the provisions of most of the industry operating agreements should be adequate to deal with the proposal, drilling and completion of such 
a horizontal well. Problems arise when portions of the target formation are owned by different working interest owners or when the same working interest owners own portions in different percentages. Given the nature of horizontal well drilling and the likelihood that it will often be geologically advisable to drill into and along a target formation crossing traditional spacing unit boundaries, there is a significant chance that ownership of the petroleum substances in the horizontal well spacing unit may vary. Further, there is a strong likelihood that in such situations no common operating agreement will exist governing the entire horizontal well spacing unit. It will be necessary for all relevant working interest owners to enter into a specific agreement as to cost sharing and ownership of production. Where there may already exist a common operating agreement with respect to the entire horizontal well spacing unit the parties must very carefully examine that agreement and the specific circumstances to see whether or not a separate agreement still needs to be entered into, since most existing industry agreements were prepared prior to the development of horizontal well technology. In most cases where there is different ownership in the same horizontal well spacing unit a new agreement as to cost sharing will be required.

Consider again the diagram appearing earlier in this paper and assume that a horizontal well is proposed that will have a horizontal borehole partly in parcel A and partly in parcel B, both of which comprise traditional spacing units for vertical wells. Assume also that parcel $A$ is owned by two working interest owners, each as to a $50 \%$ interest, and parcel B is owned by the same two working interest owners, each as to a $25 \%$ interest and by a third working interest owner as to at $50 \%$ interest. In the situation where parcel $\mathrm{A}$ and parcel B are governed by separate operating agreements, it is obvious that the parties will have to enter into a new agreement as to cost sharing and ownership of production in order to proceed with the horizontal well. This new agreement would have to deal with ownership of production, cost sharing, adoption of an operating agreement, pooling their interests, and what happens if the proposed horizontal well is unsuccessful or has to be completed as a vertical well due to technical or other problems associated with the horizontal completion.

In the situation where both parcels A and B are governed by the same operating agreement, it is important to note that both the 1981 and 1990 Canadian Association of Petroleum Landmen (CAPL) Operating Procedures provide that where parties to those agreements acquire and hold different percentages of interest in the lands subject thereto, such parties are deemed to hold such lands with different interests "as if they are parties to a separate Operating Procedure, the terms of which are identical to the terms hereof, having regard only to the different percentages of ownership interest in those lands and such portion of the joint lands shall cease to be 'joint lands' hereunder." ${ }^{189}$ In effect parcels A and B, although subject to the same operating agreement, are by virtue of this provision, deemed to be subject to two separate operating agreements as a result of the different ownership interests. This would appear to require separate operation notices, cash calls and the like to be sent with respect to each of parcels A and B, which again, 
gives rise to the need to reach a specific agreement addressing the matters discussed above.

Neither the 1981 or 1990 CAPL Operating Procedures contain a mechanism for allocating costs of a horizontal well between the parties in either of the situations outlined above. If a horizontal well is being proposed, then it is imperative that the existing operating agreements be reviewed to ensure that the proposal does not conflict with the terms of those agreements and that the issues which arise as a result of the unique nature of horizontal drilling are covered. When preparing new agreements to address horizontal drilling, the parties must be aware that even current standard form agreements such as the 1990 CAPL Operating Procedure may not address all the issues that arise with horizontal drilling.

\section{B. FREEHOLD LEASES}

The freehold lease was in existence long before horizontal drilling became a viable economic proposition. Since almost all freehold leases were prepared without contemplation of horizontal drilling, there are a number of unresolved issues which arise under these leases when horizontal drilling is used. Some of these issues are discussed below. There are a large number of different forms of freehold leases in existence and the terms of each lease have to be looked at to determine the effects of horizontal drilling for that particular lease. The Canadian Association of Petroleum Landmen Alberta 88 form of freehold lease (the CAPL Lease), an example of the most "modern" form of "operations" lease, has been used to illustrate potential problems. Clause references below, unless otherwise indicated, are to the CAPL Lease.

\section{Pooling and Unitization}

Clause 9(a) only permits pooling for the purpose of forming a "spacing unit." The term spacing unit is defined in clause $1(\mathrm{k})$ as being "the area allocated to a well from time to time on or in the vicinity of the said lands, for the purpose of drilling for or producing, as the case may be, the leased substances or any of them, as defined or prescribed by or under any statute, regulation, order or directive of any government or any governmental agency." As discussed above, horizontal wells have been and will undoubtedly continue to be drilled across a number of traditional spacing units in order to take full advantage of the technology. In these cases, the lessee will have to ensure that the spacing unit as designated by the regulations is expanded to include the entire horizontal well bore or that agreement is reached with the lessor to amend the lease to permit a pooling of more than one "spacing unit."

Clause 9(a) also requires that the pooling be on a straight acreage basis. In other words production allocated to the lands must be in the proportion that the surface area of those lands bears to the surface area of all lands in the pooled area. Given the variations in the directions in which horizontal wells may be drilled, the current uncertainty about drainage patterns of horizontal wells and the fact that horizontal wells may cross a number of traditional spacing units in which geological attributes may differ, it is likely that in many cases the allocation of production to the lands comprising the horizontal well spacing unit 
may not be equitable if done on a straight acreage basis. If it is proposed to use other than a straight acreage allocation then the agreement of all of the lessors must be obtained.

Unitization suggests itself as the preferred route under the CAPL Lease as the allocation of production is not required to be on an acreage basis, but rather is at the discretion of the lessee, acting bona fide. There are a couple of problems with this. Firstly, the vast majority of freehold leases, unlike the CAPL Lease, do not permit the lessee to unitize without the consent of the lessor. In these cases consent of the lessor to the unitization would be required just as in a non-standard pooling. Secondly, the regulatory requirements for forming a unit are much more cumbersome than for pooling. Not only would unitization result in increased costs for the lessee over a pooling but the regulatory agencies may resist the formation of a unit simply to take advantage of the provisions of the lease in the absence of technical merit or conservation considerations for the unitization.

There is also some question as to whether the courts will uphold the power granted to a lessee under a freehold lease to unitize as being valid. Some legal writers have suggested that the unitization clause contains too many "uncertainties" to be effective. Ballem in his book on freehold leases has a good discussion on this issue. ${ }^{90}$

\section{Preservation of Leases}

In the case of common ownership where the same lessees own the same working interests in two adjoining leases, each of which covers a spacing unit, the lessees might be tempted to avoid the trouble of pooling or unitizing and simply drill the horizontal well across the two spacing units. This could occur by the use of an infill well order, which does not technically result in a change of the spacing units. If a horizontal well is commenced on parcel A and parcel B contains only a horizontal section of the well then questions arise as to whether the lease respecting parcel B is preserved after the end of its primary term.

The CAPL Lease provides in the habendum clause that it will continue so long as "operations (as hereinafter defined) are conducted upon the said lands." The term "operations" is defined in clause $1(\mathrm{~g})$ (ii) to include "the production of any leased substance." The question of course, assuming it can be established that some of the petroleum substances being produced from the horizontal well are actually coming from parcel B, is whether this production is being "conducted on the said lands" as required by the habendum clause. All of the petroleum substances are coming out of the ground on parcel A so it is arguable that this is where the production actually occurs and nothing other than drainage occurs on parcel B. This would result in the lease of parcel B terminating after the end of the primary term. The presence of a portion of the horizontal 
borehole on parcel B would then give rise to the trespass issue as discussed later in this paper.

An "unless" type of freehold lease rather than an "operations" type (like the CAPL Lease) also raises some interesting questions as to continuation of the lease beyond the primary term. The "standard" unless type lease usually provides in the habendum clause that the lease continues for the primary term and "so long thereafter as the leased substances or any of them are produced from the said lands." If in the situation discussed above all that is located on the "said lands" is a portion of the horizontal borehole, then the question has to be asked whether this is sufficient to constitute production from the "said lands." If a well were located on adjoining lands and were draining the "said lands," clearly this would not be production "from the said lands" sufficient to keep the lease alive beyond the primary term. The question becomes whether the additional factor of the presence of a portion of a horizontal borehole on the said lands will be sufficient to continue the lease. This may of course be overcome if a pooling can be effected.

An interesting anomaly with the "unless" type lease is that even if the presence of a portion of a horizontal borehole on the "said lands" is sufficient to continue the lease beyond the primary term it may not be sufficient to do away with the obligation to pay the delay rental. The drilling proviso in the habendum clause of the "standard" unless lease provides that on each anniversary date the lease will terminate unless the lessee has paid the delay rental or unless operations for the drilling of a well are commenced on the said lands. It could well be argued that when only a portion of a horizontal borehole is located on the said lands the drilling of the well was never commenced on the said lands but rather was commenced on the adjoining lands. If this is the case then the presence of a portion of a horizontal borehole appears not to be sufficient to negate the obligation to continue to pay the delay rental. In these circumstances the lessee would be well advised to continue to pay the delay rental even if continuous production is being obtained from the horizontal well. This is particularly important since late payment of, or failure to pay, the delay rental under an unless type of freehold lease results in automatic termination of the lease.

In order to avoid these problems the lessee should ensure that, if a portion of the horizontal borehole will be on land subject to a freehold lease, the lease has been pooled or unitized and that this has been done strictly in accordance with the lease. If the pooling or unitization cannot be done strictly in accordance with the lease then the agreement of the lessor must be obtained to amend the lease.

\section{Offset Obligations}

As discussed above, a horizontal well will in most cases produce at a significantly greater rate than a vertical well. If a horizontal well is drilled on an adjoining spacing unit to lands subject to a freehold lease without a well on them, then the offset well clause will obligate the lessee in the case of the CAPL Lease to:

1. commence the drilling of a well (clause 8(a));

2. pool or unitize (clause $8(b)$ ); 
3. surrender the producing formation (clause 8(c)); or

4. pay compensatory royalty (clause $8(d)$ ).

Alternatives (i) and (iv) raise some interesting questions if the offset well is a horizontal well.

Since the horizontal well will have higher production rates and hence drain the reservoir faster than a vertical well, if the lessee drills a vertical well in response to an offsetting horizontal well then the lessor is going to get less royalty than if the lessee has drilled a horizontal well. The CAPL Lease simply requires that a well drilled in response to an offset well be drilled "to the same zone or formation from which production is being obtained from the offset well." There is no requirement that the well be of the same type as the offset well. The lessor might argue that since the purpose of the offset well clause is to protect from drainage there is some sort of implied obligation that the lessee must drill a well that has the best chance to drain competitively. As discussed in the section of this paper on implied covenants, it seems unlikely that this sort of implication will be supported by Canadian courts. Depending on how effectively horizontal wells drain reservoirs, in future lessors may want to consider specific provisions regarding offsetting horizontal wells in order to guard against drainage and ensure that their lands are developed to their fullest potential.

While the alternative in clause 8(a) of the CAPL Lease of drilling the well does not appear to be affected by whether or not the offset well is horizontal or vertical, the alternative of paying compensatory royalties is affected. Clause 8(d) requires the compensatory royalty to be equal to the royalty that "would have been payable to the Lessor if the leased substances produced from the offset well were actually being produced from a well on the said lands." Thus the amount of compensatory royalty that is required is likely to be greater if the offset well is a horizontal well as the production from the horizontal well is likely to be greater than a vertical well.

Another issue that arises in connection with the offset well clause is whether a horizontal well will constitute an offset well sufficient to trigger the clause in certain circumstances. Considering the diagram presented earlier in this paper, suppose that an offset horizontal well is spudded on parcel A and drilled across the boundary into the laterally adjoining parcel B. Assume further that parcel $C$ which laterally adjoins parcel $B$ but diagonally adjoins parcel $A$, is subject to a freehold lease which contains an offset well clause. If parcels $A$ and $B$ have been combined to form a single spacing unit for the horizontal well, then the offset well clause in the lease of parcel $C$ appears to have been triggered by the drilling of the well. This is particularly true in Alberta given s. 90 of the Alberta Act which reads as follows:

\footnotetext{
When a well is drilled and the well produces oil or gas from a drilling spacing unit, and oil or gas in a drilling spacing unit that laterally adjoins the first mentioned drilling spacing unit is subject to an oil or gas lease that provides for the drilling of an offset well by reason of the kind or nature of the well that produces the oil or gas, then the well shall be deemed to be in that part of the drilling spacing unit where its presence would give rise to the obligation to drill an offset well in the laterally adjoining drilling spacing unit.
} 
When a single spacing unit has been formed from parcels $A$ and $B$ for a horizontal well some interesting questions arise when a vertical well is drilled on parcel A. Clause I(f) of the CAPL Lease clearly provides that "any well drilled on any spacing unit laterally adjoining the said lands..." [emphasis added] will constilute an offset well which will trigger the offset obligation under the lease. This clause does not require that the well drilled on a laterally adjoining spacing unit must be of the type for which the spacing unit was formed. In fact the clause says just the opposite. Therefore, it is open to the lessor of parcel $C$ to argue that the offset obligation has been triggered. The fact that a well was drilled in a horizontal well spacing unit, even though it was not a horizontal well, may be enough to trigger offset obligations on leases laterally adjoining the larger horizontal well spacing unit.

If a single spacing unit has not been formed from parcels A and B either because of common ownership or otherwise, the question is whether the presence of only a portion of the horizontal borehole on parcel B is sufficient to trigger the offset well obligation in the freehold lease of parcel C. In order for the offset well obligation to be triggered under the CAPL Lease the well that has been drilled must be an "offset well." As indicated above, an "offset well" is defined in clause I( $f$ ) as "any well drilled on any spacing unit laterally adjoining the said lands...." The lessee would attempt to argue that what is located on parcel B is not a well drilled on parcel B but rather just a section of horizontal borehole. The term "well" is not defined in the CAPL Lease, however that term is defined in both the Alberta Act and the Saskatchewan Regulations. The definition which is set out in s. 1(1)(y) of the Alberta Act is as follows:

"well" means an orifice in the ground completed or being drilled

(i) for the production of oil or gas,

(ii) for injection to an underground formation,

(iii) as an evaluation well or test hole, or

(iv) to or at a depth of more than 150 metres for any purpose,

but does not include one to discover or evaluate a solid inorganic material and that does not or will not penetrate a stratum capable of containing a pool or oil sands deposit.

This definition, as set forth in the Oil and Gas Conservation Act, has been recited by Williams \& Meyers. ${ }^{91}$ Those authors go on to suggest that in some cases the United States courts have rejected the view that the term means only the hole in the ground. They cite an Illinois case in which the court found that the term included "not only the hole in the ground, but the casing and all the equipment that made it an oil well, above and below the ground." ${ }^{.92}$ It is not clear from these definitions whether the horizontal borehole underlying parcel B would constitute a "well" drilled on parcel B for the purposes of triggering the offset well clause. The lessor would argue that drainage is occurring from a laterally adjoining parcel and that is exactly what the offset well clause

92. National Oil Co. v. R.C. Cavoust Co., 51 Ill. App. (2d) 255 at 233. 
is intended to prevent. The lessor would also argue that if any portion of a well is located on the laterally adjoining spacing unit then that is sufficient to trigger the offset well clause. The resolution of this issue in the event of litigation is far from clear.

Some older freehold leases do not include the surrender and compensatory royalty alternatives contained in the CAPL Lease. In these leases a failure by a lessee to drill a well when required by the offset well clause could lead to the necessity of calculation of damages. Without getting into the complex issue of calculation of damages for failure to drill ${ }^{93}$ one wonders how the fact that the offset well is a horizontal well would affect the calculation of damages in the case of a failure to drill. The horizontal well is both more costly to drill and likely to produce greater revenues than a vertical well, both factors that could enter into the calculation of damages. On the other hand, if the obligation to drill can be satisfied by the drilling of a vertical well on the said lands does it really matter what the cost or value of a horizontal well is?

\section{ROYALTY CONSIDERATIONS}

Throughout the oil and gas industry, royalties are reserved or granted by virtue of and in conjunction with a number of common transactions. Royalties are often reserved to a farmor under a farmout agreement and in many instances such royalties are convertible upon payout of well costs. Additionally, it would not be uncommon to see a royalty specifically reserved and granted under an overriding royalty agreement stemming from a participation arrangement, a joint venture agreement, or in consideration for the rendering of geological or geophysical services. The fact that production rates have been shown to be greater in horizontal wells than in vertical wells raises a number of issues for royalties. Firstly, a flat royalty, say $2 \%$, on a horizontal well is going to generate more revenue than a $2 \%$ royalty on a vertical well even though the royalty payee pays none of the extra cost and bears none of the extra risk associated with a horizontal well. Secondly, sliding scale royalties, where the royalty rate increases with the rate of production, will likely be in the higher percentage range since production will be higher. Thirdly, in the case of royalties convertible to a working interest after payout, payout may occur much quicker due to the higher production rates, although greater drilling costs should offset this somewhat. Careful consideration will need to be given to the size of overriding royalties and in particular to the wording reserving or granting them to ensure that the intent and expectations of all parties to such agreements are met.

\section{COMMON LAW CONSIDERATIONS}

\section{A. TRESPASS}

Generally speaking there is a paucity of Canadian jurisprudence relating to the law of trespass as applicable to subsurface mines and mineral interests. Some Canadian writers have indicated that "unauthorized directional drilling through somebody else's mineral 
rights would probably constitute a trespass." ${ }^{194}$ Horizontal well technology clearly results in a greater likelihood of subsurface trespass occurring outside the lands leased by the party drilling the well than does vertical drilling.

In the United States, subsurface trespass has been given greater consideration in the courts as the evolution of oil and gas law has a longer history than in Canada. Williams \& Meyers state:

The drilling of a well bottomed on the land of another is trespass, although the surface location of the well is on the driller's own land. The intent of the driller of the directional well is immaterial to the commission of the trespass, which occurs when there is unauthorized entry upon the land of another. However, if the driller intentionally bottomed the well on another's land, the trespass is in bad faith, and the trespasser is liable for the value of the oil at the surface, ie. without a credit for drilling and operating costs. Even in the case of unintentional directional drilling resulting in good faith subsurface trespass, production from the well may be enjoined, at least where substantial injury results from the trespass. ${ }^{95}$

Given today's modern drilling technology, it would appear unlikely that a party would be successful arguing that a trespass through the horizontal drilling of a well onto someone else's land was unintentional. The drilling of any well which results in part of the well bore being on someone else's land, will likely be considered to be an intentional trespass.

In Canada, regulations have been enacted under legislation such as the Alberta Act and the Saskatchewan Act which deal with drilling target areas as indicated earlier in this paper. Where a well is completed within its target area, its production allowable or award of GPP status will not be affected by being off target. Where a well is off target, that is, completed outside of its designated target area, a penalty is imposed upon the working interest owners providing for a reduction in the assigned allowable in accordance with specific formulae contained in the regulations. Few subsurface trespass cases have come before the Canadian courts as working interest owners that complete wells off target are penalized even before those wells constitute a formal trespass into another party's mineral interests. The situations that are most likely to give rise to trespass situations are in the case of freehold leases, as discussed above, which may terminate despite the presence on the lease of a portion of horizontal well bore.

\section{B. IMPLIED COVENANTS}

The general law of implied covenants is well established in both Canada and the United States. The courts will imply the existence of a term in a contract on the basis that had the parties to the contract turned their minds to the issue they would have included such a term, or on the basis that the issue was so obvious to both parties that they did not express it. 
In Canada, however, unlike the United States, the doctrine of implied covenants with respect to common law duties under an oil and gas lease is virtually non-existent. The United States courts have developed five implied covenants for oil and gas leases. Those implied covenants are as follows:

(i) the duty to drill an exploratory well;

(ii) the duty to conduct diligent and proper operations and to manage and administer the leased premises as a reasonably prudent operator would;

(iii) the duty to protect the leased substances against drainage by wells drilled on adjoining lands;

(iv) the duty to conduct additional development drilling; and

(v) the duty to market or utilize the leased substances.

There have been discussions in the United States as to how the rapidly expanding use of horizontal drilling technology will affect the lessee's obligations under these implied covenants. ${ }^{96}$ For example, if horizontal drilling technology is widely and successfully used in a particular area, it could be argued by a lessor of a lease in that area that the lessee has an obligation under certain of these implied covenants to take advantage of the horizontal drilling technology and drill a well on the lease, perhaps even if a vertical well already exists on the lease.

In the Canadian context, three of the five implied covenants are addressed by contract or legislation. The covenant to drill an exploratory well is addressed in the habendum clause of most freehold leases; the covenant to diligently and properly operate and to manage and administer the leased premises prudently is addressed through existing conservation legislation and applicable regulations; and the covenant to protect against drainage is addressed by the offset drilling clauses in freehold leases and the requirements found in the relevant legislation and regulations.

The courts in Canada have historically not given much consideration to implied covenants but they have not ruled them out. Ballem states that "an unwritten term will be implied into a contract only in the absence of an express covenant setting out the agreement of the parties on the same point." ${ }^{197}$ The basis on which a lessor could argue for an implied term would be the business efficacy test. ${ }^{98}$ This test has been stated in a Canadian context as follows:

In some situations, although nothing has been expressly said or written by the parties with respect to a particular feature of their contract. the circumstances and the conduct of the parties may lead a court to the inevitable conclusion that, had the minds of the parties been direcled to such feature, they would have said expressly what is later alleged by one of them to have been agreed implicitly.9"

Wh,

P.A. Moore, "Horizontal Drilling: New Technology That Will Raise New Issues About 'Old' Law" The Landman, May/June 1990.

Ballem, supra, note 90 at 226. See also, Lewis and Thompson, supra, note 16, s. 121.

The Moorcock (1889), 14 P.D. 64.

G.H.L. Fridman, The Law of Contract (Toronto: Carswell, 1976) at 258. 
In the case of many early freehold leases we now have something to which the minds of the parties were clearly not directed at the time the lease was entered into because it was not an economic or even a physical possibility. That something is horizontal drilling. Without going into a detailed discussion of the law of implied covenants, it is safe to say that the lessor arguing for an implied covenant in a Canadian oil and gas lease will still have an uphill road. On the other hand, in the right fact situation, say drainage occurring by an offsetting horizontal well with the lessee refusing to drill a well because there are additional overriding royalties on the land being drained, the existence of horizontal drilling could be used by the court as a basis to imply a term to manage prudently or prevent drainage by drilling a horizontal well.

In the case of the CAPL Lease, the lessor would have the additional hurdle of getting around clause 22 which states that the lease constitutes the "entire agreement" and "no implied covenant or liability of any kind shall arise by reason hereof."

In order to protect himself from drainage and to ensure that his property is operated to his best advantage, the prudent lessor should probably now consider amendments to the offset well clause to specify the obligation that will arise if the offset well is a horizontal well.

\section{CONCLUSION}

Horizontal drilling is a new technology which is likely to be widely utilized throughout the Canadian oil and gas industry in the future. Most of the legislation and regulations as well as most industry agreements were prepared without contemplation of horizontal drilling. The regulators will have to carefully monitor their legislation and regulations to ensure that they do not needlessly hinder the development of the new technology or prevent the provinces from taking advantage of its benefits. Persons who propose to drill horizontal wells must carefully review the legislation and regulations as well as their existing leases and agreements to ensure that their proposed drilling program complies with the requirements and that new issues raised by horizontal drilling will be dealt with. 